\title{
Impact of rice fortified with iron, zinc, thiamine and folic acid on laboratory measurements of nutritional status of preschool children
}

\author{
Impacto do arroz fortificado com ferro, zinco, tiamina \\ e ácido fólico sobre as medidas laboratoriais \\ do estado nutricional de crianças pré-escolares
}

Ceres Mattos Della Lucia ${ }^{1}$

Laura Luiza Menezes Santos ${ }^{1}$

Bárbara Pereira da Silva ${ }^{1}$

Pamella Cristine Anunciação ${ }^{1}$

Rita de Cássia Gonçalves Alfenas ${ }^{1}$

Sylvia do Carmo Castro Franceschini ${ }^{1}$

Hércia Stampini Duarte Martino ${ }^{1}$

Helena Maria Pinheiro Sant'Ana ${ }^{1}$

${ }^{1}$ Departamento de Nutrição

e Saúde, Universidade Federal de Viçosa. Av.

PH Rolfs s/n, Campus Universitário. 36570-

000 Viçosa MG Brasil. cmdellalucia@ufv.br

\begin{abstract}
Fortification of food constitutes an important strategy for the control of micronutrient deficiency and has advantages such as high population coverage and maintenance of eating habits. This study aimed to assess the impact of using fortified rice (Ultra Rice $\left.{ }^{\circledast}-U R^{\otimes}\right)$ on the nutritional status of preschoolers. Ninety-nine children enrolled in two philanthropic preschools participated of the study. Children of one of the preschools were offered $U R^{\otimes}$ mixed with polished rice, as part of school meals (test group) and the children of another preschool were offered pure polished rice (control group). Biochemical evaluations were performed before and after 4 months of intervention. Dietary assessment and sensory evaluation of $U R^{\circ}$ mixed with polished rice were performed during the study. The fortified rice improved the concentrations of zinc $(p<0.001)$, thiamine $(p<$ $0.001)$, folic acid ( $p=0.003$ ), mean corpuscular hemoglobin $(p<0.001)$ and mean corpuscular hemoglobin concentration $(p<0.001)$. The fortified rice showed good acceptability among preschoolers. This study demonstrated the effectiveness of using rice fortified with iron, zinc, thiamine and folic acid on the nutritional status of children.
\end{abstract}

Key words Biochemical assessment, Dietary intake, Anemia, Food history, Ultra rice
Resumo A fortificação de alimentos constitui importante estratégia para o controle da deficiência de micronutrientes e apresenta como vantagens a alta cobertura populacional e o fato de não alterar hábitos alimentares. O presente estudo teve como objetivo avaliar o impacto do uso de arroz fortificado (Ultra Rice ${ }^{\oplus}-\mathrm{UR}^{\oplus}$ ) sobre o estado nutricional de pré-escolares. Noventa e nove crianças matriculadas em duas creches filantrópicas participaram do estudo. Para crianças de uma creche foi oferecido UR ${ }^{\otimes}$ misturado com arroz polido, como parte das refeições escolares (grupo teste) e para as da outra foi oferecido somente arroz polido (grupo controle). Avaliações bioquímicas foram realizadas antes e após 4 meses de intervenção. Avaliações dietética e sensorial do UR ${ }^{\circledR}$ misturado com arroz polido foram realizadas durante o estudo. $O$ arroz fortificado melhorou as concentrações de zinco $(p<0,001)$, tiamina $(p<0,001)$, ácido fólico $(p=0,003)$, hemoglobina corpuscular média ( $p$ $<0,001)$ e hemoglobina corpuscular média ( $p<$ 0,001). O arroz fortificado mostrou boa aceitação entre os pré-escolares. Este estudo demonstrou a eficácia do uso de arroz fortificado com ferro, zinco, tiamina e ácido fólico sobre o estado nutricional das crianças.

Palavras-chave Avaliação bioquímica, Ingestão alimentar, Anemia, História alimentar, Ultra rice 


\section{Background}

Disturbances in nutritional status, particularly those related to micronutrient deficiency, may be caused by multiple factors ${ }^{1}$. These deficiencies are risk factors for health and survival of vulnerable groups, such as preschool children ${ }^{2,3}$. Minerals and vitamins deficiency may also be present in overweight individuals, interfering in the entire development process, with physical, social and economic consequences ${ }^{4}$.

Micronutrient deficiencies may occur simultaneously ${ }^{5}$ and have serious consequences on children's health. Nutritional status influences learning ability and performance of children in school, since a qualitatively and quantitatively adequate diet is essential for the maturation of neurological structures that favor the learning process. Because children in developing countries generally reach school age with problems of chronic malnutrition, the school should guide to increase micronutrients intake, reducing their deficiency ${ }^{6}$.

Therefore, it is necessary to use strategies to prevent nutritional disorders, such as food fortification, which is the first alternative intervention recommended for localities of greatest prevalence ${ }^{7}$.

Rice is a staple food and fortification vehicle in countries where people suffer from micronutrient deficiencies because it is one of the most popular cereals around the world ${ }^{8}$. Therefore, rice fortified with micronutrient based on the Ultra Rice ${ }^{\circledast}$ technology $\left(\mathrm{UR}^{\circledast}\right)$ may prevent nutritional deficiencies in many age groups, because its grains can be fortified with one or more nutrients and used by specific populations according to their most urgent needs ${ }^{7}$. Thus, this study evaluated the effect of UR ${ }^{\circledast}$ fortified with iron, zinc, thiamine and folic acid on the nutritional status of preschool children.

\section{Subjects and Methods}

\section{Test Food}

Rice grains extruded from rice flour (Ultra Rice $\left.^{\circledast}\left(\mathrm{UR}^{\circledast}\right)\right)$, produced and provided by a pasta manufacturer after authorization by the Program for Appropriate Technology in Health (PATH), were used. The grains contained iron (in the form of micronized ferric pyrophosphate), zinc (in the form of zinc oxide), thiamine (in the form of thiamine mononitrate) and folic acid. The grains were mixed with polished rice, at a proportion of 1:100 and served at lunch.

Dosage of the micronutrients in $\mathrm{UR}^{\circledast}$ took into account factors such as losses in processing, transport, storage and cooking, as well as bioavailability of the compounds used in fortification. These losses are considered in the formulation, so that the target levels are reached in cooked rice. The children received, in means, $50 \mathrm{~g}$ portion of this preparation that contains $0.5 \mathrm{~g}$ of $\mathrm{UR}^{\circledast}$ and meets, after cooking, approximately one third (33.33\%) of the Recommended Dietary Allowances (RDA) of these micronutrients for this population group 9 . In this case, $0.5 \mathrm{~g}$ of raw $\mathrm{UR}^{\circledast}$ contain $4.2 \mathrm{mg}$ of iron, $2.1 \mathrm{mg}$ of zinc, $0.36 \mathrm{mg}$ of thiamine (vitamin $\mathrm{B}_{1}$ ) and $72 \mathrm{mg}$ of folic acid.

\section{Sample}

The sample size was calculated according to Mera et al. ${ }^{10}$, considering ferritin as the main variable $^{11}$. A statistical power of $80 \%$, a significance level of $5 \%$ and an expected difference of $17 \%$ in the baseline values were adopted, totaling a sample of 45 individuals in each experimental group.

The study was conducted in two philanthropic preschools in Brazil. One hundred and forty-three children between 2 and 6 years old, of both genders, were considered eligible to participate in the study. Children whose hemoglobin $(\mathrm{Hb})$ levels were equal to or greater than $11.0 \mathrm{~g} / \mathrm{dL}$ were included in the study. Children diagnosed with iron deficiency anemia, who received ferrous sulfate supplementation or other nutritional supplements after evaluation by a qualified doctor of the city Health Department, were excluded from the study for ethical reasons since the fortified rice is a food testing. A total of 131 children were selected, of which blood was taken from 112 after obtaining parental consent. Of those, 13 did not return for the dietary assessment, yielding a total of 99 children who participated in all sessions of the study (Figure 1). The preschools were randomly selected as "control" or "test".

\section{Experimental design}

This is a four months intervention study, in which children of the selected preschools received, as part of school meals, polished rice (control group) or $\mathrm{UR}^{\oplus}$ mixed with polished rice (test group). Rice portions (50g) were served daily, Monday through Friday. Children were sub- 
mitted to laboratory tests before and after the intervention period (Figure 2). Laboratory tests

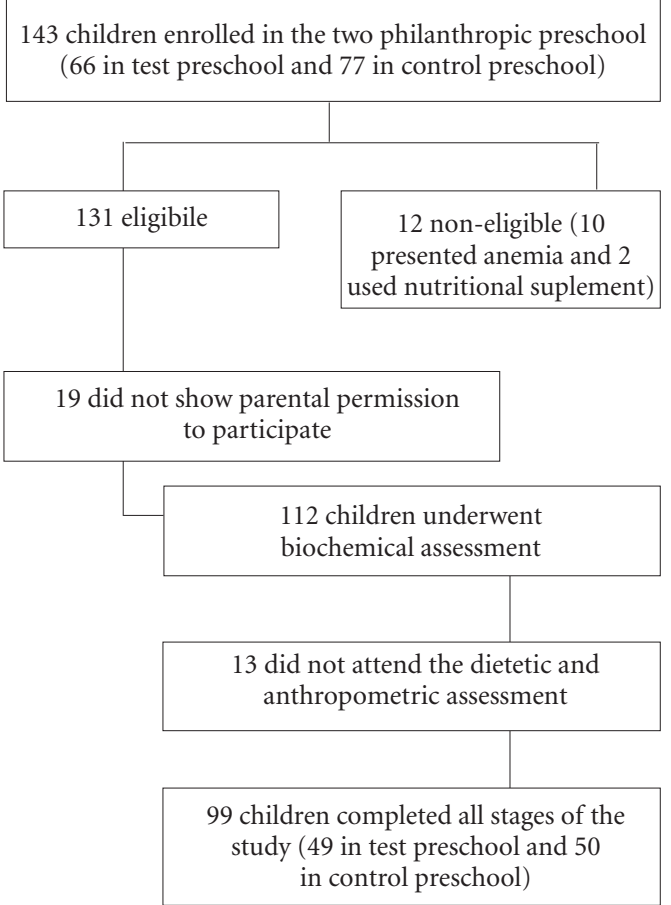

Figure 1. Scheme of sample selection of children enrolled in two philanthropic preschools. were conducted at Laboratory of Clinical Analyses, Division of Health of the Federal University of Viçosa (UFV). Before initiating the study, children were dewormed with Albendazole (oral suspension, $40 \mathrm{mg}$ ), as medically indicated.

\section{Laboratory tests}

Laboratory tests were conducted at the beginning and end of the intervention period. Samples containing approximately $12 \mathrm{~mL}$ of blood were collected in syringes by venipuncture. About $4 \mathrm{~mL}$ of the sample were transferred to a tube containing anticoagulant ethylene diamine tetraacetic (EDTA) to perform full blood count and erythrocyte thiamine; $4 \mathrm{~mL}$ were transferred to a serum-gel tube for analysis of serum folate and ferritin ultrasensitive CRP, and the remaining blood $(4 \mathrm{~mL})$ was transferred to a draw tube for determination of serum zinc.

Analysis of folic acid and ferritin were performed by chemiluminescence method and serum zinc by atomic absorption spectrophotometry. Erythrocyte thiamin (thiamine diphosphate) was analyzed by High Performance Liquid Chromatography (HPLC) according to Mancinelli et al. ${ }^{12}$.

Mean corpuscular volume (MCV), mean corpuscular hemoglobin $(\mathrm{MCH})$ and mean corpuscular hemoglobin concentration (MCHC) were calculated as the ratio between hemoglobin and red blood cells.

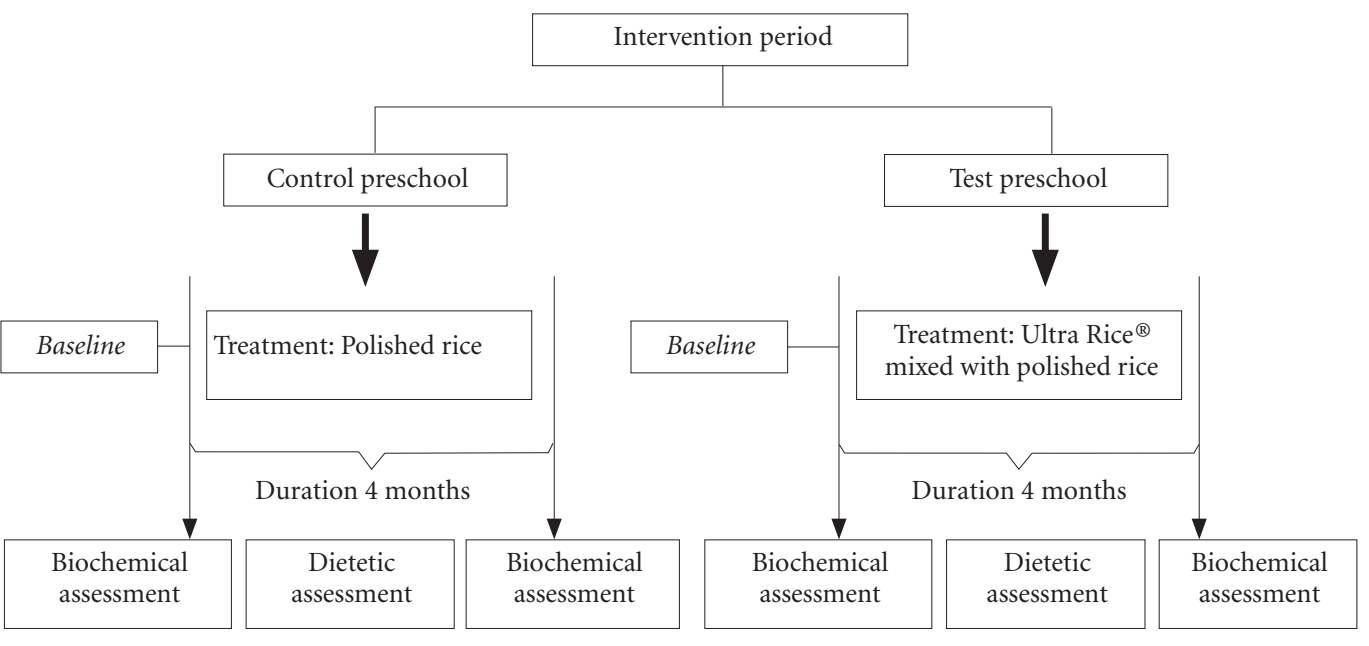

Figure 2. Experimental design of the intervention study with preschool children. 


\section{Dietary assessment}

Meals offered at preschools were directly weighed (weighing the ingested food $=$ weigh of food provided - food actually consumed) and the food intake analysis was complemented with a $24 \mathrm{~h}$ recall. This analysis happened at the middle of the time of the study. For standardization of data one interviewer were trained, and a standard form was used for application of the food record method.

The average of three samples of the served $\mathrm{UR}^{\circledast}$ was obtained to increase precision. Food was weighed on a calibrated digital scale with a capacity of $5 \mathrm{~kg}$ and precision of $1 \mathrm{~g}$. Solid foods were weighed on a pre-weighed plate and liquid foods (soups, juices) were weighed in plastic cups. The preparation method was recorded and the ingredients weighed for all foods served to the children.

To control the intrapersonal variability of dietary intake of children in school, a second intake assessment was performed by randomly reweighing $25 \%$ of the children evaluated. This was performed at an interval of at least one day between collections, repeating the collection procedure of the first assessment. Contents of iron, zinc, vitamins $B_{1}, C$ and folic acid were calculated using Avanutri software, version 2.0.

\section{Evaluation of $\mathrm{UR}^{\circledast}$ acceptance by preschool children}

To evaluate the acceptance of $\mathrm{UR}^{\circledast}$ by preschool children the "Rest-Ingestion" test was applied $^{13}$. Acceptability of the foods and the respective preparations were also evaluated by the Acceptability Index (AI), which relates the amount of the meal consumed with the amount of the meal distributed according to the following equation:

$$
\mathrm{AI}=\frac{\begin{array}{c}
\text { total weight of the preparation } \\
-(\text { surplus }+ \text { leftovers })
\end{array}}{\text { weight of the preparation }- \text { surplus }}
$$

Where:

Surplus: Quantity of the preparation not distributed to the children;

Leftovers: Quantity of the preparation distributed to the children that was not ingested, leftover on the plate.
The rice was prepared following the menu used in the preschool. Rice was weighed, placed on individual plates and offered to the children. After ingestion, the containers were collected and the leftovers gathered and weighed. The surplus was also weighted.

\section{Statistical analyses}

The database was developed with the help of the Excel (Microsoft Excel 2007) software. Statistical tests were performed using the program SigmaPlot - Scientific Data Analysis and Graphing Software, version 11.0.

The Kolmogorov-Smirnov test was used to assess the normality of the data. To evaluate potential differences between the medians of the variables in the two groups, the Mann-Whitney test was used, adopting a 5\% significance level $(\mathrm{p}<0.05)$. To analyze the effect of intervention with UR ${ }^{\circledast}$, and biochemical data collected at the beginning and end of the intervention was compared using the Wilcoxon test when there was no normal distribution of data, and by the paired t-test when the distribution was normal, using a significance level of $5 \%(\mathrm{p}<0.05)$.

\section{Ethical Aspects}

The protocol of this study was approved by the Ethics Committee on Research with $\mathrm{Hu}$ man Beings of the Federal University of Viçosa (UFV). Those responsible for the children were informed about the study and the confidentiality of the information, and signed the Statement of Informed Consent, authorizing participation of the child.

Clarifications were made in accessible language and free consent to participate in the research was guaranteed to all individuals, as recommended by the Guidelines and Rules of Research Involving Human Subjects of the National Health Council ${ }^{14}$.

Parents or guardians received a summary of the laboratory tests of the child. For children presenting malnutrition, Nutrition counseling was provided to the children and their parents. At the end of the study, parents received nutritional guidance with respect to feeding of their children, in the form of seminars, with utilization of posters and brochures. After completion of the study, children enrolled in the control group also received the fortified rice, as part of school meals, during the same period in which it was received by children of the test group. 


\section{Results}

\section{Characterization of the sample}

More than half of the participants $(53.5 \%, \mathrm{n}$ $=53)$ were female, $47.5 \%(\mathrm{n}=47)$ of them were 2-3 years old and $52.5 \%(n=52)$ were $4-6$ years old (median age was 4 in the test preschool and 3 in the control preschool).

\section{Laboratory tests}

At baseline, children in both groups were homogeneous in relation to concentrations of erythrocytes, hemoglobin, hematocrit, mean corpuscular volume (MCV), mean corpuscular hemoglobin $(\mathrm{MCH})$, mean corpuscular hemoglobin concentration (MCHC), folic acid, thiamine, serum zinc and C-reactive protein (CRP) $(\mathrm{p}>0.05)$.

At the end, the values of $\mathrm{MCH}(\mathrm{p}<0.001)$, MCHC $(p<0.001)$, folate $(p<0.003)$ and serum zinc $(\mathrm{p}<0.001)$ increased when compared to the beginning of the study in the test group (Table 1). In both groups erythrocyte thiamine concentration increased at the end of the study $(\mathrm{p}<0.001)$. Serum ferritin concentration was higher at the end of the study in control group ( $\mathrm{p}$ $<0.001)$. At the beginning of the study, children in the test group showed higher concentrations of erythrocyte thiamin $(\mathrm{p}=0.012)$ and ferritin $(\mathrm{p}<0.001)$ (Table 1).

\section{Dietary assessment}

Vitamin $B_{1}$, folate, calcium and iron intakes was higher in the test preschool when compared to the control preschool, which presented higher vitamin $C$ intake in both age groups studied (Table 2).

\section{Evaluation of the acceptance of UR ${ }^{\circledast}$ by preschool children}

The acceptance index (AI) was high (98\%). Acceptance values greater than $85 \%$ indicate that preparations or foods may successfully be provided on a continuous basis ${ }^{13}$.

\section{Discussion}

The UR ${ }^{\circledast}$ improved the nutritional status of preschool children in relation to the concentrations of zinc, thiamin, folic acid, $\mathrm{MCH}$ and $\mathrm{MCHC}$.
Test group showed higher intake of vitamin $\mathrm{B}_{1}$, folate, calcium and iron when compared to the control group, which presented higher vitamin C intake in both age groups. Greater intake of vita$\min \mathrm{B} 1$, iron and folate in the test group may be attributed to the fortified rice (UR ${ }^{\circledast}$ ) consumption, since this product is enriched with these micronutrients. Although the $\mathrm{UR}^{\oplus}$ is also fortified with zinc, there was no difference regarding mean intake of this mineral between the test and control groups, due to greater consumption of foods considered sources of zinc by children of the control group. It is important to note that only the intake of fortified rice was monitored, and the school menus and home meals were not controlled during the intervention period.

Erythrocytes, hemoglobin and hematocrit were similar in both groups between the beginning and end of the intervention period. This can be explained by children adequate nutritional iron status, i.e., they did not present anemia at the beginning of the experiment. When iron levels absorbed by the diet are adequate, the intestinal mucosa regulates its absorption to maintain a constant amount of iron in the body, which would explain the similarity in values of the variables described previously ${ }^{15}$. However, values of $\mathrm{MCH}$ and $\mathrm{MCHC}$ increased after consumption of fortified rice by children of the test group, indicating a possible reduction of hypochromic red blood cells, and therefore any effect of fortified rice on the nutrition state of iron among these children.

At the beginning of the study, thiamine concentrations of the control group were lower than those of the test group. Thus, even without the use of fortified rice in school meals of the control preschool, improved nutritional status of this nutrient was observed possibly due to its increased uptake at the intestinal level.

These findings corroborate with the results observed in the dietary assessment, since the children of the test group showed greater intakes of vitamin $B_{1}$, folate and iron. Although children of the test group presented improved nutritional status of zinc at the end of the intervention period, the intake of this mineral did not appear different between the evaluated preschools.

The serum ferritin concentration was higher at the end of the study in children of the control group. Analysis of food consumption revealed factors that may explain the higher iron stocks in children of the control preschool, such as the intake of calcium, vitamins A and C. Calcium intake was higher in the test preschool children. Al- 
Table 1. Biochemical variables of preschool children in the test and control groups, before and after the intervention.

\begin{tabular}{|c|c|c|c|c|}
\hline \multirow{2}{*}{ Variables } & \multicolumn{4}{|c|}{ Test Preschool } \\
\hline & Before intervention & After intervention & Difference & $\mathrm{p}^{\mathrm{a}}$ \\
\hline Erythrocytes (millions $/ \mathrm{mm}^{3}$ ) & $\begin{array}{c}4.90 \pm 0.32 \\
\quad(4.92)\end{array}$ & $\begin{array}{c}4.85 \pm 0.36 \\
\quad(4.87)\end{array}$ & $\begin{array}{c}-0.04 \pm 0.27 \\
(-0.04)\end{array}$ & 0.305 \\
\hline Hemoglobin (g/dL) & $\begin{array}{c}12.34 \pm 0.80 \\
(12.10)\end{array}$ & $\begin{array}{c}12.54 \pm 0.88 \\
(12.30)\end{array}$ & $0.19 \pm 0.64(0.00)$ & 0.111 \\
\hline Hematocrit (\%) & $\begin{array}{c}39.27 \pm 2.27 \\
(39.05)\end{array}$ & $\begin{array}{c}39.14 \pm 2.82 \\
(38.60)\end{array}$ & $\begin{array}{c}-0.13 \pm 2.16 \\
(-0.20)\end{array}$ & 0.696 \\
\hline $\operatorname{MCV}(\mathrm{fL})$ & $\begin{array}{c}80.33 \pm 4.29 \\
(80.94)\end{array}$ & $\begin{array}{c}80.66 \pm 3.95 \\
(81.54)\end{array}$ & $\begin{array}{l}0.32 \pm 1.24 \\
\quad(0.27)\end{array}$ & 0.097 \\
\hline $\mathrm{MCH}(\mathrm{pg})$ & $\begin{array}{c}25.22 \pm 1.53 \\
(25.59)\end{array}$ & $\begin{array}{c}25.74 \pm 1.53 \\
\quad(26.08)\end{array}$ & $\begin{array}{l}0.52 \pm 0.63 \\
\quad(0.60)\end{array}$ & $<0.001$ \\
\hline $\mathrm{MCHC}(\%)$ & $\begin{array}{c}31.37 \pm 0.56 \\
(31.40)\end{array}$ & $\begin{array}{c}31.87 \pm 0.66 \\
(31.85)\end{array}$ & $\begin{array}{l}0.50 \pm 0.73 \\
\quad(0.45)\end{array}$ & $<0.001$ \\
\hline Folicacid (ng/mL) & $\begin{array}{c}17.62 \pm 3.08 \\
(19.50)\end{array}$ & $\begin{array}{c}19.72 \pm 5.08 \\
(21.00)\end{array}$ & $2.10 \pm 5.99(3.20)$ & 0.003 \\
\hline Thiamine $(\mu \mathrm{g} / \mathrm{L})$ & $\begin{array}{c}72.12 \pm 25.85 \\
(66.67)\end{array}$ & $\begin{array}{c}194.76 \pm 93.33 \\
(145.84)\end{array}$ & $\begin{array}{c}122.64 \pm 98.62 \\
(85.11)\end{array}$ & $<0.001$ \\
\hline Ferritin $(\mathrm{ng} / \mathrm{mL})$ & $\begin{array}{c}32.80 \pm 15.89 \\
(30.65)\end{array}$ & $\begin{array}{c}34.17 \pm 16.10 \\
(28.45)\end{array}$ & $\begin{array}{c}1.82 \pm 14.50 \\
(2.75)\end{array}$ & 0.082 \\
\hline Serumzinc $(\mu \mathrm{g} / \mathrm{dL})$ & $\begin{array}{c}80.97 \pm 11.88 \\
(81.40)\end{array}$ & $\begin{array}{c}110.21 \pm 22.76 \\
(108.80)\end{array}$ & $\begin{array}{c}29.25 \pm 23.31 \\
(26.30)\end{array}$ & $<0.001$ \\
\hline $\mathrm{CRP}(\mathrm{mg} / \mathrm{dL})$ & $\begin{array}{c}0.26 \pm 0.59 \\
\quad(0.01)\end{array}$ & $\begin{array}{l}0.12 \pm 0.32 \\
\quad(0.02)\end{array}$ & $-0.15 \pm 0.44(0.00)$ & 0.128 \\
\hline
\end{tabular}

\begin{tabular}{|c|c|c|c|c|c|}
\hline \multirow{2}{*}{ Variables } & \multicolumn{5}{|c|}{ Control Preschool } \\
\hline & Before intervention & After intervention & Difference & $\mathrm{p}^{\mathrm{a}}$ & P baseline ${ }^{b}$ \\
\hline Erythrocytes (millions $/ \mathrm{mm}^{3}$ ) & $\begin{array}{c}4.86 \pm 0.42 \\
\quad(4.95)\end{array}$ & $\begin{array}{c}4.90 \pm 0.34 \\
\quad(4.92)\end{array}$ & $\begin{array}{c}0.04 \pm 0.29 \\
\quad(0.00)\end{array}$ & 0.367 & 0.670 \\
\hline Hemoglobin $(\mathrm{g} / \mathrm{dL})$ & $\begin{array}{c}12.40 \pm 0.87 \\
(12.30)\end{array}$ & $\begin{array}{c}12.57 \pm 0.95 \\
(12.50)\end{array}$ & $\begin{array}{c}0.18 \pm 0.64 \\
(0.10)\end{array}$ & 0.079 & 0.781 \\
\hline Hematocrit (\%) & $\begin{array}{c}38.87 \pm 2.68 \\
(38.40)\end{array}$ & $\begin{array}{c}39.17 \pm 2.62 \\
(38.75)\end{array}$ & $\begin{array}{c}0.29 \pm 2.21 \\
(0.25)\end{array}$ & 0.334 & 0.464 \\
\hline MCV (fL) & $\begin{array}{c}80.20 \pm 4.81 \\
(80.56)\end{array}$ & $\begin{array}{c}80.05 \pm 4.71 \\
(79.54)\end{array}$ & $\begin{array}{c}-0.16 \pm 2.16 \\
(0.30)\end{array}$ & 0.628 & 0.769 \\
\hline $\mathrm{MCH}(\mathrm{pg})$ & $\begin{array}{c}25.59 \pm 1.95 \\
(25.90)\end{array}$ & $\begin{array}{c}25.61 \pm 1.86 \\
(25.53)\end{array}$ & $\begin{array}{l}0.02 \pm 1.02 \\
\quad(0.16)\end{array}$ & 0.223 & 0.314 \\
\hline $\mathrm{MCHC}(\%)$ & $\begin{array}{c}31.89 \pm 0.78 \\
(31.99)\end{array}$ & $31.97 \pm 0.68(32.20)$ & $\begin{array}{l}0.08 \pm 0.77 \\
\quad(0.22)\end{array}$ & 0.079 & 0.866 \\
\hline Folicacid (ng/mL) & $\begin{array}{c}17.38 \pm 5.28 \\
(17.35)\end{array}$ & $\begin{array}{c}17.58 \pm 4.23 \\
(17.35)\end{array}$ & $\begin{array}{l}0.20 \pm 5.11 \\
\quad(0.00)\end{array}$ & 0.796 & 0.962 \\
\hline Thiamine $(\mu \mathrm{g} / \mathrm{L})$ & $\begin{array}{c}58.29 \pm 16.51 \\
(53.69)\end{array}$ & $\begin{array}{c}101.19 \pm 61.23 \\
(95.19)\end{array}$ & $\begin{array}{c}42.89 \pm 33.50 \\
(37.19)\end{array}$ & $<0.001$ & 0.012 \\
\hline Ferritin $(\mathrm{ng} / \mathrm{mL})$ & $12.38 \pm 0.84(12.30)$ & $36.45 \pm 15.34(34.50)$ & $\begin{array}{c}24.07 \pm 15.53 \\
(21.70)\end{array}$ & $<0.001$ & $<0.001$ \\
\hline Serumzinc $(\mu \mathrm{g} / \mathrm{dL})$ & $\begin{array}{c}95.86 \pm 21.90 \\
(95.40)\end{array}$ & $92.13 \pm 15.92(92.10)$ & $\begin{array}{c}-3.73 \pm 27.76 \\
(-7.20)\end{array}$ & 0.378 & 0.070 \\
\hline CRP (mg/dL) & $\begin{array}{c}0.36 \pm 1.06 \\
(0.03)\end{array}$ & $\begin{array}{c}0.34 \pm 0.57 \\
\quad(0.10)\end{array}$ & $\begin{array}{c}-0.02 \pm 1.15 \\
(0.01)\end{array}$ & 0.226 & 0.516 \\
\hline
\end{tabular}

MCV: mean corpuscular volume; MCH: mean corpuscular hemoglobin; MCHC: mean corpuscular hemoglobin concentration; CRP: C-reactive protein. Results obtained by biochemical analysis, expressed in mean \pm standard deviation, median (minimum and maximum) of variables of 2 to 6 year-old children after 4 months of study. $\mathrm{n}=99$ children ( 49 in test preschool and 50 in the control preschool). Bold values: $\mathrm{p}<0.05$. ${ }^{\mathrm{a}} \mathrm{p}$ values for comparison of variables medians in the same preschool, before and after intervention period. Wilcoxon test (non-parametric distribution). ${ }^{\mathrm{b}} \mathrm{p}$ values for comparison of variables medians between the two preschools in the beginning of the study. Mann-Whitney test (non-parametric distribution). 
Table 2. Nutrients intakes of the preschool children $(n=99)$.

\begin{tabular}{|c|c|c|c|}
\hline \multirow{3}{*}{ Variables } & \multicolumn{2}{|c|}{$2-3$ year-old children } & \multirow{3}{*}{$\mathbf{P}$} \\
\hline & \multicolumn{2}{|c|}{ Mean \pm SD Median $($ Min - Max $)$} & \\
\hline & Test Preschool & Control Preschool & \\
\hline Vitamin $B_{1}(m g)^{\star *}$ & $\begin{array}{c}1.28 \pm 0.33 \\
1.28(0.69-2.14)\end{array}$ & $\begin{array}{c}0.96 \pm 0.32 \\
0.91(0.31-1.75)\end{array}$ & 0.003 \\
\hline $\operatorname{Vitamin} \mathrm{C}(\mathrm{mg})^{\star}$ & $\begin{array}{c}48.64 \pm 66.36 \\
24.09(11.08-322.76)\end{array}$ & $\begin{array}{c}64.79 \pm 50.63 \\
50.81(21.54-221.74)\end{array}$ & 0.006 \\
\hline Vitamin A (RE) & $\begin{array}{c}276.82 \pm 621.66 \\
206.12(40.21-1300.38)\end{array}$ & $\begin{array}{c}304.93 \pm 125.47 \\
271.12(94.55 \pm 561.74)\end{array}$ & 0.090 \\
\hline Folate $(\mu \mathrm{g})^{*}$ & $\begin{array}{c}99.68 \pm 31.05 \\
92.46(57.68-171.58)\end{array}$ & $\begin{array}{c}51.78 \pm 22.99 \\
43.87(21.54-96.57)\end{array}$ & $<0.001$ \\
\hline Iron $(\mathrm{mg})^{* *}$ & $\begin{array}{c}8.94 \pm 1.65 \\
9.11(5.52-11.81)\end{array}$ & $\begin{array}{c}7.55 \pm 2.18 \\
7.53(3.61-12.20)\end{array}$ & 0.021 \\
\hline $\operatorname{Zinc}(\mathrm{mg})^{*}$ & $\begin{array}{c}5.31 \pm 1.39 \\
5.02(3.23-8.30)\end{array}$ & $\begin{array}{c}6.98 \pm 5.93 \\
5.67(3.27-33.70)\end{array}$ & 0.207 \\
\hline Calcium (mg) & $\begin{array}{c}827.62 \pm 255.93 \\
802.89(494.62-1392.31)\end{array}$ & $\begin{array}{c}520.35 \pm 250.55 \\
518.78(123.50-993.42)\end{array}$ & $<0.001$ \\
\hline \multirow{3}{*}{ Variables } & \multicolumn{2}{|c|}{$4-6$ year-old children } & \\
\hline & \multicolumn{2}{|c|}{ Mean \pm SD Median (Min-Max) } & $\mathbf{P}$ \\
\hline & Test Preschool & Control Preschool & \\
\hline 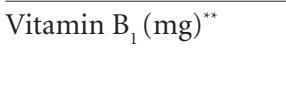 & $\begin{array}{c}2.70 \pm 1.60 \\
2.18(0.98-7.53)\end{array}$ & $\begin{array}{c}1.19 \pm 0.49 \\
1.04(0.75-2.71)\end{array}$ & $<0.001$ \\
\hline Vitamin C (mg)* & $\begin{array}{c}36.34 \pm 28.23 \\
29.66(6.66-128.62)\end{array}$ & $\begin{array}{c}99.66 \pm 94.73 \\
74.79(16.86-456.33)\end{array}$ & $<0.001$ \\
\hline Vitamin A (RE) & $\begin{array}{c}435.41 \pm 893.06 \\
248.04(38.74-4994.90)\end{array}$ & $\begin{array}{c}392.43 \pm 207.05 \\
367.61(117.70-947.14)\end{array}$ & 0.040 \\
\hline Folate $(\mu \mathrm{g})^{*}$ & $\begin{array}{c}218.19 \pm 170.54 \\
160.79(53.16-790.18)\end{array}$ & $\begin{array}{c}54.34 \pm 24.61 \\
44.91(24.22-125.75)\end{array}$ & $<0.001$ \\
\hline Iron $(\mathrm{mg})^{* *}$ & $\begin{array}{c}10.34 \pm 4.04 \\
11.90(5.92-13.52)\end{array}$ & $\begin{array}{c}8.78 \pm 2.19 \\
9.05(4.60-12.50)\end{array}$ & $<0.001$ \\
\hline Zinc $(\mathrm{mg})^{*}$ & $\begin{array}{c}10.83 \pm 14.53 \\
7.11(3.13-83.60)\end{array}$ & $\begin{array}{c}9.22 \pm 12.39 \\
5.86(3.97-65.30)\end{array}$ & 0.063 \\
\hline Calcium (mg) & $\begin{array}{c}668.73 \pm 220.91 \\
601.91(321.96-1306.57)\end{array}$ & $\begin{array}{c}495.70 \pm 195.45 \\
443.50(190.08-908.68)\end{array}$ & 0.004 \\
\hline
\end{tabular}

Results obtained by direct weighing of food complemented with a $24 \mathrm{~h}$ record, expressed in mean \pm standard deviation, median (minimum and maximum) of variables of 2 to 6 year-old children after 4 months of study. $n=99$ children ( 49 in test preschool and 50 in the control preschool). ${ }^{*}$ Mann-Whitney Rank Sum test (non-parametric distribution). ${ }^{* *}$ T-test (parametric distribution). Min $=$ Minimum, Max $=$ Maximum. Bold values: $\mathrm{p}<0.05$.

though calcium has a negative influence on iron bioavailability, the mechanism by which dietary calcium reduces iron absorption is still poorly understood. There is some competitive inhibition between calcium and iron in the final transport of intestinal mucosa to the plasma, which occurs for heme and non-heme iron ${ }^{16}$.

Vitamin A intake was higher among children between 4-6 years old in the test group, which may be another possible explanation for the higher iron stocks in these children at the end of the study. Vitamin A has an effect on iron metabolism; however, this mechanism is not completely understood. It is possible that this vitamin interferes with the mobilization of available iron stocks and the use of iron to form hemoglobin ${ }^{17}$, i.e., the concentrations of ferritin may be reduced in children with greater consumption of vitamin A. 
Consumption of vitamin $\mathrm{C}$, which was higher in children of the control group, is also a factor that may explain the higher ferritin concentrations in these children. When this vitamin is present in adequate amounts, its rapid effect on iron absorption percentage is noted ${ }^{18}$.

Serum ferritin concentrations were higher before intervention among children in the test group, which may also explain the more evident increase in relation to this variable in children of the control group, whose ferritin levels were lower.

This is the first study to assess the effectiveness of UR ${ }^{\circledast}$ on biochemical variables in non-anemic children. Although all children were within the limits of normality for all variables analyzed, there was improvement in the nutritional status relative to the micronutrients in the fortified rice.

Studies evaluated the effect of using UR ${ }^{\circledast}$ on the nutritional status of iron in different population groups. In a study, $\mathrm{UR}^{\circledast}$ and a placebo solution were administered to a group of children with mild anemia $(n=175)$ (test group: $\left.\mathrm{UR}^{\circledast}\right)$. After 5 months, the serum ferritin and hemoglobin concentrations increased in both groups, although change in the test group was higher ( $\mathrm{p}$ $<0.05)^{19}$. These children had mild anemia, unlike the present study, in which no difference was observed in hemoglobin concentrations at the end of the intervention period.

Others studies also demonstrated that rice fortified intake reduced the prevalence of iron deficiency anemia in children and adults ${ }^{20,21}$. In the present study, it was not possible to assess the impact of $\mathrm{UR}^{\circledast}$ on reducing the prevalence of anemia, since anemic or iron deficient children did not participate in the study.

The $\mathrm{UR}^{\circledast}$ added to polished rice showed an excellent acceptance. Although the facial hedonic scale is the most recommended method to evaluate the acceptability of preparations, being fit for illiterate children ${ }^{22}$, for children of this age group the AI may be in a better parameter to evaluate acceptance of a preparation, because very young children may have difficulty understanding small differences in facial expression on the five-point hedonic scale.

Reports encountered in literature deal only with studies of acceptability for fortified rice in adults, so this is the first study in which children assess acceptance of $\mathrm{UR}^{\circledast}$ mixed with polished rice. As an example, when using a 7-point hedonic scale applied to 37 untrained adult judges, the authors of a study ${ }^{19}$ obtained average scores of acceptance between 5 and 6 for the attributes appearance, color, odor and taste, ranging between the hedonic terms "liked" and "really liked", indicating that iron and the other micronutrients used in this rice fortification process did not cause changes in the sensory characteristics of the final product. In a study conducted in India, 24 women assessed rice fortified with ferric pyrophosphate, containing 3 to $5 \mathrm{mg}$ of iron/100 $\mathrm{g}$ of rice, by means of triangular tests and could not distinguish the fortified rice from conventional rice, both in its raw and cooked form ${ }^{20}$.

\section{Conclusions}

Greater intake of vitamin $B_{1}$, iron and folate in the test preschool may be attributed to the consumption of fortified rice $\left(\mathrm{UR}^{\circledast}\right)$. The $\mathrm{UR}^{\circledast} \mathrm{im}$ proved the nutritional status of preschool children in relation to the concentrations of zinc, thiamin, folic acid, MCH and MCHC.

Sensory acceptance of UR ${ }^{\circledast}$, evaluated by the acceptability index, was excellent according to the children. This study provided useful information on the nutritional status of preschool children enrolled in Brazilian philanthropic preschools and has demonstrated the effectiveness of the use of rice fortified with iron, zinc, thiamine and folate on nutritional status of these children. 


\section{Collaborations}

CMD Lucia wrote the project, collected and analyzed the data and wrote the manuscript; LLM Santos, BP Silva e PC Anunciação analyzed the data and wrote the manuscript; SCC Franceschini, HS Duarte Martino and RCG Alfenas helped to wrote and correct the manuscript; HMP Sant'Ana oriented the students, helped to write the project and corrected the manuscript.

\section{Acknowledgments}

The authors thank PROBIC/FAPEMIG, PIBIC/ CNPq and FAPEMIG for the financial support and PATH for the donation of the fortified rice.

\section{References}

1. Mariath AB, Giachini RM, Lauda LG, Grillo LP. Estado de ferro e retinol sérico entre crianças e adolescentes atendidos por equipe da Estratégia de Saúde da Família de Itajaí, Santa Catarina. Cien Saude Colet 2010; 15(2):509-516.

2. Martins MC, Oliveira YP, Coitinho DC, Santos LMP. Panorama das ações de controle da deficiência de vitamina A no Brasil. Rev Nutr 2007; 20(1):5-18.

3. Leal LP, Osório MM. Validação e reprodutibilidade de sinais clínicos no diagnóstico de anemia em crianças Validity and reproductibility of the clinical signs for the diagnosis of anemia in children. Cad Saude Publica. 2005; 21(2):565-572.

4. Nutti MR, Carvalho JLV, Watnabe E. A biofortificação como ferramenta para combate a deficiências em micronutrientes. Brasília: Embrapa; 2006.

5. Sena KCM, Pedrosa LFC. Efeitos da suplementação com zinco sobre o crescimento, sistema imunológico e diabetes. Rev Nutr 2005; 18(2):251-259.

6. Costa EQ, Ribeiro VMB, Ribeiro ECO. Programa de alimentação escolar: espaço de aprendizagem e produção de conhecimento. Rev Nutr 2001; 14(3):225-229.

7. Zancul MS. Fortificação de alimentos com ferro e vitamina A. Medicina 2004; 37:45-50.

8. Dexter PB. Rice Fortification For Developing Countries [database on the Internet]. USAID. 2012. [cited 2016 Mar 1]. Avaliable from: http://pdf.usaid.gov/ pdf_docs/Pnacd279.pdf

9. National Research Council. Committee on Dietary Allowances. National Research Council, Food and Nutrition Board. Recommended dietary allowances. Washington: National Academy Press; 1980.

10. Mera R, Thompson H, Prasad C. How to calculate sample size for an experiment: a case-based description. Nutr Neurosci 1998; 1(1):87-91.

11. Radhika MS, Nair KM, Kumar RH, Rao MV, Ravinder P, Reddy CG, Brahmam GN. Micronized ferric pyrophosphate supplied through extruded rice kernels improves body iron stores in children: a double-blind, randomized, placebo-controlled midday meal feeding trial in Indian schoolchildren. Am J Clin Nutr 2011; 94(5):1202-1210.

12. Mancinelli R, Ceccanti M, Guiducci MS, Sasso GF, Sebastiani G, Attilia ML, Allen JP. Simultaneous liquid chromatography assessment of thiamine, thiamine monophosphate and thiamin diphosphate in human erythrocytes: a study on alcoholics. J Chromat B 2003; 789(2):355-363.

13. Centro Colaborador em Alimentação e Nutrição Escolar CECANE-UNIFESP. Manual para aplicação dos testes de aceitabilidade no Programa Nacional de Alimentação Escolar - PNAE. São Paulo: CECANE-UNIFESP; 2010.

14. Conselho Nacional de Saúde (CNS). Diretrizes e normas regulamentadoras de pesquisa envolvendo seres humanos. Brasília: CNS; 1997.

15. Carvalho MC, Baracat ECE, Sgarbieri VC. Anemia ferropriva e anemia de doença crônica: distúrbios do metabolismo de ferro. Segur alim nutr 2006;13(2):54-63.

16. Gleerup A, Rossander-Hulthén L, Gramatkovski E, Hallberg L. Iron absorption from the whole diet: comparison of the effect of two different distributions of daily calcium intake. Am J clin nutr 1995; 61(1):97-104. 
17. Osório MM. Fatores determinantes da anemia em crianças. J pediatr 2002; 78(4):269-278.

18. Lynch SR. Interaction of iron with other nutrients. $\mathrm{Nu}$ trition Reviews 1997; 55(4):102-110.

19. Beinner MA, Velasquez-Meléndez G, Pessoa MC, Greiner T. Iron-fortified rice is as efficacious as supplemental iron drops in infants and young children. J nutr 2010; 140(1):49-53.

20. Moretti D, Zimmermann MB, Muthayya S, Thankachan P, Lee T-C, Kurpad AV, Hurrell RF. Extruded rice fortified with micronized ground ferric pyrophosphate reduces iron deficiency in Indian schoolchildren: a double-blind randomized controlled trial. Am J clin nutr 2006; 84(4):822-829.

21. Hotz C, Porcayo M, Onofre G, García-Guerra A, Elliott T, Jankowski S, Greiner T. Efficacy of iron-fortified Ultra Rice in improving the iron status of women in Mexico. Food Nutr Bull 2008; 29(2):140-149.

22. Kimmel SA, Guinard J. Sensory testing with young children. Food technol 1994; 48(3):92-94

Artigo apresentado em 17/11/2015

Aprovado em 22/07/2016

Versão final apresentada em 24/07/2016 